\title{
A Study on the Political Economy of Transforming Indigenous Technology in Nigeria through Appropriate Engineering and Technological Development
}

\author{
${ }^{1 *}$ Akpojedje, F. O., \& ${ }^{2}$ Ighodaro, H. F. \\ ${ }^{1}$ Department of Electrical and Electronic Engineering, National Institute of Construction Technology, Uromi, Nigeria; ${ }^{2}$ Department of Social Sciences, \\ National Institute of Construction Technology, Uromi, Nigeria \\ *Corresponding author's e-mail: francetech007@yahoo.com
}

\begin{abstract}
This paper examines the political economy of transforming indigenous technology in Nigeria through suitable engineering and technological development. The existing state of position of the indigenous technology with respect to its problems as it affects socio-economic growth, good governance and technological advancement were looked into. After in-depth evaluation, it was mirrored that there were some obstacles in the transformation of the nation's indigenous technology to meet global standards. Therefore, this paper proposes the 3-I (imitation, improvement and innovation) technological advancement model as the way forward to start spiral process model of technological innovation that will aid the transformation of the indigenous technology to stimulate political-economic and technological advancement of the country. Economic growth will go side by side with technological advancement and national social security but the government is an indispensable entity in the developmental process.
\end{abstract}

\begin{tabular}{l} 
Keywords \\
\hline Appropriate engineering \\
and technology; \\
Developing economy; \\
Governance; \\
Indigenous \\
technology; \\
Political economy, \\
Technological \\
development pattern.
\end{tabular}

Received 10 Oct. 2018; Revised 11 Dec. 2018; Accepted 15 Dec. 2018; Available online 2 Jan. 2019.

Copyright (C) 2019 The Authors. This is an open access article under the CC BY-NC-ND license (http://creativecommons.org/licenses/by-nc-nd/4.0/)

\section{Introduction}

It is critically essential that in contemporary economics, the level of growth rate of any nation's economic output is a function of being able to transform its indigenous technology to meet global standards. In the developed economy of the world, technological uplift is positively responsible for more than half of the growth in output over time. The economic growth of both developing and developed countries depends upon it (Park et al., 2011). In spite of this, Nigeria and other Sub-Saharan countries do not place much emphasis on developing their indigenous technology. They invariably use rudimentary and even obsolete technologies and processes (Iyoha, 2004). Specifically, if technical progress is embodied in the capital stock, then an increase in investment will yield not only more capital but newer, better and more productive capital as well. This will have the effect of increasing the elasticity of the growth rate of output with respect to the growth of capital (Iyoha, 2004).

Nigeria as late-comer in the industrial race is supposed to be at an advantage since there are already existing quantity of techniques, products and processes that have already been developed in the advanced economy globally. Thus, it is important for the Nigerian government to take advantage of this availability to develop her indigenous technology to optimise good governance through the provision of durable social infrastructures and stimulate economic growth. Technological advancement and management can be considered as the key driving force in the development of any economy (Park et al., 2011). The concept of indigenous technology transformation and development in Nigeria is very essential, if its fortune must change to technological driven economy. This will help in the production of goods and services that are competitive in the local and international market.

A key factor inhibiting Nigeria's technological advancement is the failure of the government, stakeholders and people to critically examine the necessity of the local technology. Local industries and

Article citation: Akpojedje, F. O., \& Ighodaro, H. F. (2019). A Study on the Political Economy of Transforming Indigenous Technology in Nigeria through Appropriate Engineering and Technological Development. Journal of Advances in Science and Engineering, 2(1): 1-8. https://doi.org/10.37121/jase.v2i1.30 
technologies are essential part of people's culture; as they symbolise the additive mechanism through which people can survive in any ecological niche they find themselves. Moreover, local technology should serve as the basis for the technological development of any nation (Ibeanu \& Okonwo, 2014). The concept of Foucault (1988), which always function together but irreducible to one; comprises the technologies of production, power and techniques of the self (Martin et al., 2002).

Transformation and development of local technology is a thing of commitment and self-reliance after passing through the technological advancement cyclic model (Akpojedje \& Abu, 2016). One of the fundamental problems responsible for the backwardness of Nigeria technology is the politicisation of its technological growth and ideology. This has resulted in the massive importation of foreign goods and services that reduce and hinder the strive for the effective competitiveness of indigenous industries with those in the advanced economy. Hence, one can say that the lack of pursuit for good governance is a major factor for Nigeria and indeed in Africa technological backwardness. This was why Manabete \& Umar (2014) made it obvious that "one fundamental problem responsible for the technological backwardness of West Africa and indeed, the whole Africa is the inability of the government, stakeholders and people in the region to explore indigenous viable options".

Changes in technology when properly harnessed by the political class, government and stakeholders can lead to increase in capital, productivity of labour and other factors of production. Osaigie (1996) asserted that the performance of an economy is a function of the economic policy framework and the effectiveness of the implementation process. Kuznets (1955) traced five distinct patterns in the development of technology in modern economic progress to scientific discovery or an addition to technical knowledge, an invention, transformation (an innovation), an improvement, and the spread of invention usually accompanied by improvements. These factors have helped in the development of the technology for modern economic growth. Notwithstanding, development of less developed countries (LDCs) must import the modern technology to accelerate their productive capacity by developing their indigenous technical skills. This paper looks at the transformation of Nigeria indigenous technology through appropriate engineering and technological advancement to advance socio-economic and technological growth to meet global standards.

\subsection{Definition of Terms}

This section expressly defined the key terms that are used in this paper as follows:

Local technology: The term local (indigenous) basically refers to native or home-grown; while technology is the art and science of applying knowledge to meet human needs (Okorafor, 2014). Abdulkareem (2013), defined technology as "the art and science of applying man's knowledge in human endeavours' so as to satisfy man's needs". The International Technology Education Association (ITEA) defined technology as the use of knowledge, skills and resources to meet people's needs and wants by developing practical solution to problems, taking social and environmental factors into consideration (ITEA, 2002). Technology can also be defined as the application of knowledge towards the design and fabrication of devices, tools and appliances to better the condition of man (Manabete \& Umar, 2014). Technology can be accepted as putting human knowledge, acquired skills, experience, philosophy and resources to meet people's needs and wants (Akpojedje \& Mormah, 2017).

Political economy: Political economy refers to interdisciplinary studies drawing upon economics, sociology and political science in explaining how political institutions, the political environment and the economic system - capitalist, socialist, communist or mixed - influence each other (Weingast \& Wittman, 2008). Essentially, it is the interplay or inter-connectivity between politics and economics vis-a-vis other disciplines or phenomenon. Political economy as a concept is mainly inspired by the growing interest on interdisciplinary studies. In other words, political economy is the mixture of politics, economics, sociology, etc. to bring about growth of an economy and it is a major determinant of economic outcomes of a nation.

Developing economy: A developing economy is a nation that has low capital formation and the inability to produce enough goods and services to meet local needs and wants. Nigeria is a typical example of a country that has a developing economy. According to Iyoha (2004), a developing economy probably has a low level of technology, inadequate supply of social overhead capital (the availability of roads, railways, ports, etc.) tends to be insufficient, low energy consumption per capital, high percentage of the population employed in agriculture, a low life expectancy at birth, high infant mortality, and low average food intake (protein-calorie intake is inadequate). A developing economy is said to be underdeveloped. Essentially, "a country that is underdeveloped will always find itself in a stable low income level equilibrium trap (Iyoha, 2004). 


\section{Contemporary State of Indigenous Technology in Nigeria}

Despite abundant mineral resources available in Nigeria and her counterpart countries in Sub-Sahara Africa, the populace continue to face monumental development challenge. Today in Nigeria, a good percentage of about $61.2 \%$ of her population live on less than one dollar (\$1) a day (Aiyedogbon \& Ohwofasa, 2012). Most of the mineral resources in Nigeria are exported without adding value to them as export. When the abundant mineral resources in Nigeria are properly harnessed through appropriate engineering and technology; it will positively improve the nation's economy.

According to Akpojedje \& Abu (2016), a nation is technologically backward and in bad shape if it is unable to produce her own military hardware to defend herself, if the need arises; depends on foreign countries for the supply of spare parts for industrial machinery; unable to explore and export her natural resources, except with the help of foreign expatriates; cannot produce capital goods such as tractors, lathe machines, milling machines, cars, trains and other earth moving equipment; and exports her raw materials to other nations as against finished product. An examination of these features indeed demonstrate that Nigeria is a technologically backward economy.

\subsection{Factors Inhibiting Indigenous Technological Transformation in Nigeria and their Applications}

There are numerous factors that inhibit indigenous technological drive, advancement and development, and their applications in Nigeria. Some of them are as follows:

Entrepreneurship inbibition in Nigeria: Transformation of indigenous technology in Nigeria is being faced with entrepreneurship inhibition where the social system desires opportunities for creative faculties. The forces of custom, the rigidity of status and the distrust of new ideas and of the exercise of intellectual curiosity, combine to create an atmosphere inimical to experiment and innovations (Jhigan, 2005). As a result of all these, it becomes difficult to imbibe new techniques (skills) and ideas in the production of goods and services. By this, the techniques and skills of production remain at the rudimentary level. This has led to low output and technological backwardness of the local industries in the country

Infrastructural decadence: The level of decay of public infrastructure in Nigeria cannot be overemphasised. The majority of industries in Nigeria have been operating under excess capacity since the late 1980's. The main reasons for this is that there are no good public utilities such as; adequate power supply, good housing etc., because they are in a state of decadence. This has led to frustration of indigenous technology, a situation where industries are not in a position to work to their full capacity. Consequently, there is a shifting of quite a number of indigenous industries in the country (Nigeria) to neighbouring countries where they can have optimal output as a result of the availability of good public utility.

Foreign trade orientation: Nigeria economy is generally foreign trade-oriented. This fact is reflected in the exports of primary products and imports of consumer goods and machinery. Hence, there is over dependent on foreign industries in the countries. The problem of over dependent on foreign technologies constitute a serious threat and setback to the development of the local technology (Manabete \& Umar, 2014). Thus, too much dependence on the exportation of primary products leads to serious repercussions on the Nigerian economy; where it concentrates mainly on the production of primary exports to the comparative neglect of the other sectors of the economy for technological growth and development.

Non-commercialisation of academic research: In Nigeria today, academic research papers and publications are merely done for the purpose of routine academic promotions and recognitions. But the producer/user synergy ought to determine the commercial value of research papers. Typically, the commercial values of most research papers and publications are very low and less valued in relation to the industries (Akpojedje and Abu, 2016).

Nigeria as a dumping ground for sub-standard goods: The Nigeria market is often flooded with foreign substandard goods. This hinders the impetus for indigenous industries in the country to grow and develop their technology. Besides, the local industries then find it difficult to compete with those being imported. The indigenous industries invariably use rudimentary and even obsolete technologies and processes; hence, it becomes impossible them to produce at large or commercial scale as a result of inadequate market for its product and services.

Government policy inconsistency and instability: The different tiers of government in the country make policies that are never consistent or consonance with any previous government. This instance hinders the growth and development of indigenous technology in the country causing a fluctuation that distorts its technological pursuit. It is only when there is consistency and stability in science and technological policy that the local technology can advance in Nigeria. 
Moral decadence: The prevalent of moral decadence like corruption and greed have eaten deep into all facet in the Nigerian economy; of which its science and technological sector is not an exception. Corruption is like cancerous plague that has hindered the growth and development of indigenous technological advancement in the country (Akpojedje \& Abu, 2016). Funds allocated for technological advancement, perhaps, are only on papers that may never be accounted for efficiently. It is generally known that Nigerian government measures progress and achievement in terms of funds allotment (Onipede, 2010); but what they do with these funds allocated are not always accounted for. This actually stand as impediment to the growth and advancement of indigenous technology in the country. Public finance and expenditures budgeted on the construction and provision of social infrastructure are diverted to private pockets and shoddy infrastructure that will not stand the test of time are commissioned on daily basis. Therefore, local technology is still left to remain at rudimentary level without the quest for improvement.

Inadequate patronage of goods from indigenous technology: It is worrisome that the government only pay lipservice to engineering and technology as a result of inadequate funding of local engineering and technological institutions and other research institutions. In Nigeria, between 1985 and 2000, research funds averaged only $0.08 \%$ of the Gross National Product (GNP) which is a far cry from the UNESCO recommended target of $1.0 \%$ (Oke, 2005).

Death of undocumented technology: Most indigenous technology in the country (Nigeria) is not documented; hence, it becomes impossible for such to be transferred from one person to another when who originate it dies. This, in most cases, has led to the loss of indigenous technologies and knowledge.

Poor buman capacity building: The government often finds it difficult to recognise any local intellectual individual or group. This factor has worsened the set-back of indigenous technological advancement; bringing it to its lowest ebb. Hence, there is poor human capacity building as individuals or groups are not encouraged into technological discovery and breakthrough in Nigeria.

Disconnection between industries and research institutes: Most research institutes in Nigeria usually engage in researches that are not in-line with the needs of the industries in the country. This is virtually one of the key reasons why the synergy between industries and research (academic) institutes is feeble. This gap accounts for the poor technological growth and advancement in the country.

\subsection{Political Economy of Developmental Prospect of Indigenous Technology in Nigeria}

Despite the poor patronage of goods and services manufactured and delivered by indigenous technology in Nigeria, it still has numerous positive prospects for development if properly harnessed. According to the Innomantra (2011), the transformation of local technology when pursued actively via proper involvement of stakeholders in engineering and technology, will offer Nigeria vast technological, political and economic developmental opportunities:

(a) It can promote good governance through the production of durable social infrastructure and the delivering of social essential services. The transformation of indigenous technology through appropriate engineering and technology can make it possible for durable social infrastructures such as roads, bridges and power stations that will stand the test of time to be built by the government at all levels. This can promote good governance and the ripple effect of effective production of goods and services in the Nigerian societies. This will encourage indigenous construction companies and those involved in the delivery of services to become competitive like their counterpart in the developed economy and meet up with the global standards.

(b) It can help the nation in the attainment of self-reliance in technological arena. When indigenous technology is transformed, it can make the goods, most especially capital goods in the country to be competitive with those produced in the developed economy. By this, capital goods such as machines, electronics, vehicles and others that can make the country to be self-reliance in technological height will be produced locally to meet global standards.

(c) It can stimulate economic growth along with provision of employment opportunities for its citizenry. Indigenous production of durable goods and services will earn foreign exchange to the Nigerian economy through their export. Thus, removing Nigerian economy from the status of export of primary products to that of capital or secondary products. This will in no doubt increase the foreign reserve, financial base and value of its currency (Naira). Also, this can on the long run create employment opportunities and a drastic reduction of youth restiveness and crime in the society to its barest level.

(d) It can increase capacity building of technical skills and entrepreneurial development of the nation. The transformation of indigenous technology in Nigeria through appropriate engineering and technological development can uplift the technical skills and entrepreneurial base to be able to meet
$4 \mid \mathrm{P}$ a g e
I S S N : $2636-607 \mathrm{X}$ 
global quality and standard. Besides, this will stimulate the export of indigenous entrepreneurial goods and services, which must have been produced through appropriate engineering and technology.

(e) The practice can increase the standard of living and reduce the cost of the nation when properly harnessed; thereby developing its economy for the wellbeing of the populace. Through the transformation of the local technology, the standard of living of the people will be secured and a corresponding reduction in the cost of living. This can be achievable through an increase in the volume of goods and services being produced through appropriate engineering and technology.

(f) It can also serve as good opportunities for innovation, modernisation and technological competitiveness. This will give a viable opportunity for entrepreneurs to express themselves in the production of globally standardised and acceptable goods and services. This creativity and innovativeness will be built among the indigenous entrepreneurs through appropriate engineering and technology.

(g) It can stimulate industrialisation and domestic capacity building, which is a key to national development.

For Nigeria, it implies that "indigenous knowledge and technology offer a wide spectrum of opportunities for development” Manabete \& Umar (2014).

\section{Adaptation and Development Model of Local Technology}

The advancement of indigenous technology can be looked at as a cyclic process. Most industrialised countries of the world stimulate their indigenous technologies by the adoption of the "spiral process model cyclic" during their developmental phases, and such innovations pass through this cyclic process (Akpojedje \& Abu, 2017).

The first stage is when indigenous firms begin their invention process from international transfer of technology via duplicative imitation. This phase is followed by the adaptation of the imported technologies via the assimilation and subsequent improvement and development. This phase is sometime called creative imitation stage. According to Park et al. (2011), "these imported technologies are further improved upon by processing the imported technologies using their own indigenous knowledge, local initiatives and technological capabilities," and this is accomplished by means of the spiral process model of technological advancement. Moreover, countries like China, Japan, Korea, Singapore and Taiwan advanced their local technology through the adoption of the spiral process model. Typically, Japan was able to develop her technology after the Second World War as a result of imported technologies and most especially in the 1950's. Many Japanese companies started their technological novelty by assimilating and applying foreign technologies, which empowered them to confront the industrial leadership in the US and Europe. Moreover, American mechanical capacities were established due to application and assimilation of British in the eighteen century, when US imported steam engine technology from the Great Britain. So, it is evidenced that the US technological innovation capabilities also passed through the same pattern (Park et al., 2011).

The above pattern of technological transformation and growth is known as the "spiral process model of technological advancement" as illustrated in Figure 1.

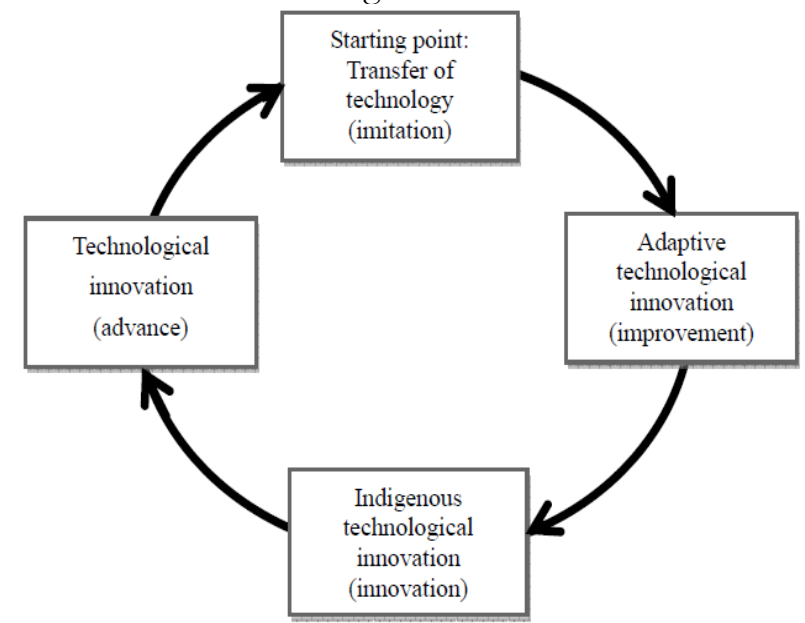

Figure 1. Spiral process model of technological advancement (Park et al., 2011) 
The first stage of the spiral process model of technological advancement is for indigenous technology of a developing economy to import foreign technology. After acknowledging the appropriate technologies, the second stage is for the country receiving the foreign technology to adopt it. The third phase is for the recipient and developing country to launch its own local and indigenous knowledge. The final stage, which is the derivative platform is the breakthrough of technologies in the developed countries; and this phase is called technological advancement. Nigeria can adopt this spiral process model of technological advancement to develop its own indigenous technology based on imitation, assimilation and innovation pattern.

\section{Enhancing Indigenous Technology in Nigeria through Appropriate Technological Transformation and Support}

In order to stimulate the growth, development and transformation of Nigeria indigenous technology to meet global standards, all hands must be on desk (stakeholders) for it to be achieved. Nigeria has not been able to develop its indigenous technological and engineering capabilities because it has not been successful in adopting, imitating and improving the imported technology using its local knowledge to meet its local needs and wants. Nigeria has made giant strides in design, fabrication, refining and development of local technologies, especially in the agricultural sector, which include maize shelter, cassava planter and harvester, cassava peeling machine, crop transplanter, cowpea thresher, cocoa plantation weeding machine and groundnut harvester (Manabete \& Umar, 2014).

With new techniques coming into the markets of advanced countries, it becomes necessary for such countries to ship out the excess of old techniques to countries with low or very low techniques. Therefore, except Nigeria transform its indigenous technology, it will perpetually be dependent on their original benefactors (Advanced economy). It becomes obvious that countries with high concentration of skills have tendency to be more developed than those with less skills (Okoduwa, 2003). The Nigerian government should have the "political will" to transform the indigenous technology to meet its populace local needs and wants. Thus, this align with Nnamdi (2004), that "politics is always concerned with the question "what means are adopted by the state for the satisfaction of its needs?" Transformation of indigenous technology will lead to spontaneous economic growth. The quest for economic growth is understandable since it can improve the well-being of the poor and increase the welfare of all members of society (Iyoha, 2004).

The stimulation of indigenous technology through appropriate technological transformation and support is made up of primary and secondary sections in this paper. The primary section considers the role of government (stakeholders) in supporting the transformation of indigenous technology to meet local needs as well as global standards for sustainable economic growth in Sub-Saharan Africa. Conversely, the secondary section adopts the technological imitation, improvement and innovation (3-I) pattern strategy of local technological development and transformation proposed by Park et al. (2011).

\subsection{Role of Government (Stakeholders) in Supporting the Transformation of Indigenous Technology}

In order to transform the nation's indigenous technology and social infrastructure through appropriate engineering and technological development to meet global standards, the Nigerian government should put the following into consideration:

(a) Technical oriented policy: There should be an urgent need by the Nigerian government to always promulgate social, economic policies that are technically oriented. Besides the government, other stakeholders should make policies that technologically drive and abstain from any form of policy that will retrogress technological development.

(b) Giving more attention to technical education: The government and stakeholders should prioritise technical education in the country. This can be complemented by updating and stocking of the technical laboratories with better and more tools and equipment to work with; while the use of obsolete ones should be discouraged

(c) Adequate funding of research and development: The government should adequately fund and encourage a bilateral relationship between industries and technical institutions in the country.

(d) Commercialisation of research and development: There should not be a disconnection between the results obtained through research and development $(\mathrm{R} \& \mathrm{D})$ in institutions and industries. In addition, any relevant output from $\mathrm{R} \& \mathrm{D}$ should be practically put into use by industries in order to encourage novelty and discovering in the country technological development and advancement. 
(e) Strengthening capacity building: It is important for the Nigerian government to strengthen the capacity building of science and technology in the country; as well as the basic technical skills, which are also a prerequisite for future development.

\subsection{Adoption of the Technological Imitation, Improvement and Innovation (3-I) Pattern of Development and Transformation}

The secondary section of the technological transformation is the adoption of foreign (imported) technology through the 3-I technological advancement strategy; as such pattern is the best option for many developing countries like Sub-Saharan African to start the spiral process of technological advancement (Park et al., 2011). Nigeria can emulate countries like China, Japan, Korea and other contemporary developed countries, which adopts the 3-I technological advancement strategy in order to have the same result. Nevertheless, the government is an indispensable entity in 3-I technological development as shown in Figure 2.

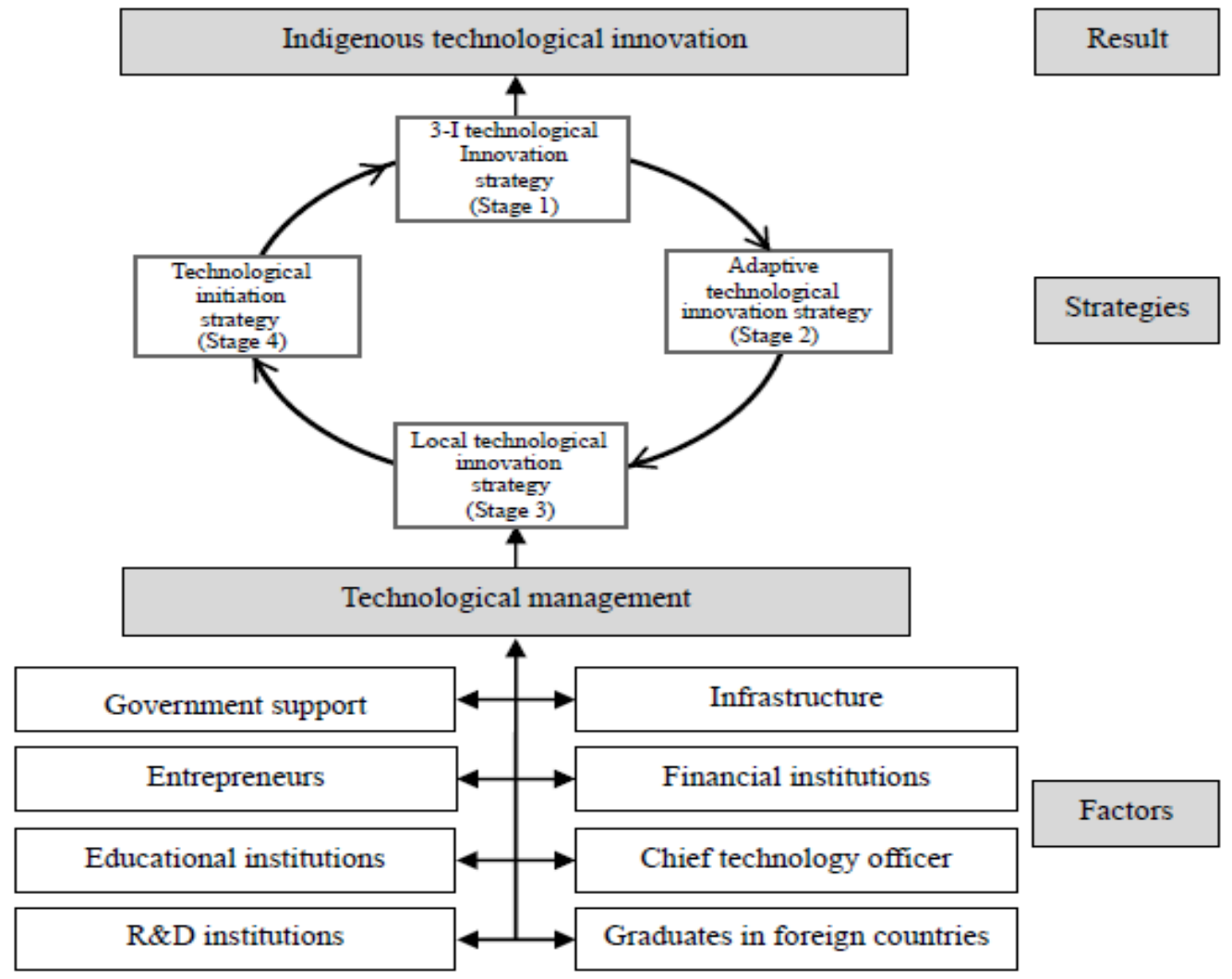

Figure 2. Building model of local technology advancement (Park et al., 2011).

Local technological innovation can be commercialised successfully as entrepreneurs will benefit the users, which will lead to the prosperity of the society as shown in the cyclic model for local technological advancement in Figure 3.

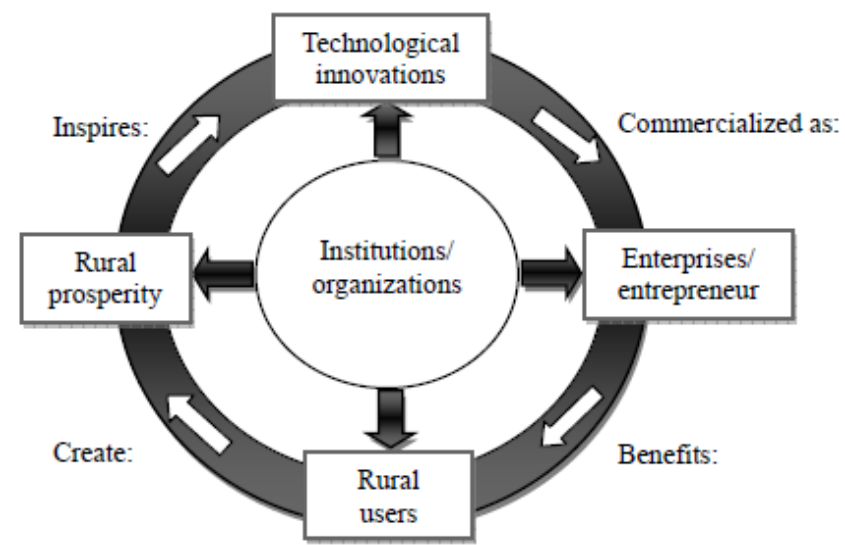

Figure 3. Cyclic model for local technological advancement (Park et al., 2011) 
A deep look and examination of Figure 3 shows an in-depth bilateral relationship between industries and research institutions in Nigeria. This will lead to inspirations of indigenous technological innovation as entrepreneur/enterprise will assist rural users and generate affluence, thereby developing the indigenous content of the country. Nigeria can become industrialised like her counterpart in the technological advanced countries if the models proposed in this paper are adequately implemented.

\section{Conclusion}

It has indeed been established that a country is not great among the comity of nations when it is endowed with abundant natural resources but how the natural resources are harnessed through adequate transformation of its indigenous technology by the import of advanced foreign technology. One of the major challenges facing Nigeria in technological advancement is the inefficient use of its available natural (both human and material) resources. The transfer of highly concentrated skilled manpower from advanced countries to the less developed ones is one of the advantages derived from trade. However, Nigeria as a country has been making some efforts to transform its indigenous technology; but without a commensurate result. The barriers have been adequately captured and looked into in this paper. Nigeria still have the opportunities to be part of the technological advanced economy in the world by appropriate transformation of its indigenous engineering and technology via the adoption and application of the 3-I technological advanced pattern as illustrated in this paper. Hence, economic growth will go side by side with technological advancement and national social security.

\section{Conflict of Interests}

The authors declare that there is no conflict of interests regarding the publication of this paper.

\section{References}

Abdulkareem, Y. A. (2013). Indigenous technology: past, present and future. Paper presented at the Raw Materials Research and Development Council Workshop for the Processing of Raw Materials, Kwara State.

Aiyedogbon, J. O, \& Ohwofasa, B. O. (2012). Poverty and youth unemployment in Nigeria, 1987 - 2011, International Journal of Business and Social Science, 3(20): $269-279$.

Akpojedje, F. O. \& Abu, Y. O. (2016). Transforming local technology in Sub-Saharan Africa through appropriate engineering and technological development to meet global standards. Journal of Multidisciplinary Science and Technology, 3(7): 5324-5330.

Akpojedje, F. O., \& Mormah, E. C. (2017). Appropriate engineering and technology: a stimulant for African economic transformation and sustainability. World Wide Journal of Multidisciplinary Research and Development, 3(10): 48-53.

Foucault, M. (1988). Technologies of the self. In L/H/ Martin, H. Gutman \& Hutton, P. H. (Eds.). Technologies of the self: A seminar with Michael Foucault. Cambridge: MIT Press.

Ibeanu, A. M., \& Okonkwo, E. E. (2014), Indigenous technology and cultural practices in Umudu, Nigeria, Chapter. Retrieved from http://www.unn.edu.ng/publications/files/12030_Indigenous_Technology_and_Cultural_Practices_in_Umundu,_Nigeria.pdf (December 1, 2016).

Innomantra Consulting Private Limited (2011). Indigenous technology: a neglected blessing. Retrieved from http://www.innomantra.com (August 20, 2015).

International Technology Education Association (2002). Standard for technological literacy: content for the study of technology. Reston: ITEA.

Iyoha, M. A. (2004). Macro-economics: theory and policy. Benin, Mondex Publishing

Jhigan, M. L. (2005). The economic of development and planning. Delhi, Vrinda Publications Ltd.

Kuznets, S. (1955). Economic growth and income inequality, in Jhingan, M. L. the economics of development and planning, 43, Delhi, Vrinda Publications Ltd.

Manabete, S. S., \& Umar, B. (2014). Indigenous technology for sustainable development in West Africa. Journal of Education and Practice, 5(37): 54-62.

Martin, L. H., Gutman, H., \& Hutton, P. H (Eds) (2002). Technologies of the self, A seminar with Michael Foucault, Cambridge MIT Press. International Education Association.

Nnamdi, H. S. (2004). Nigerian government and politics. Lagos: Trust Publishing.

Oke, J. S. (2005). An evaluation of the Nigerian innovation system and technological capability building in the manufacturing sector. A Ph.D. Thesis submitted to Obafemi Awolowo University, Ile-Ife.

Okoduwa, A. P. (2003). Global trade: trade and policy. Benin: Mindex Press.

Okorafor, A. O. (2014). Developing indigenous technology for harnessing local natural resources in Nigeria: the place of technical education and training. International Journal of Science and Technology, 3(8): 461

Onipede, K. J. (2010). Technology development in Nigeria: the Nigerian machine tools industry experience. Journal of Economics, 1(2): $85-90$.

Osagie, E. (1996). Macro-economic policy analysis tools, Obadan, M. I. \& Iyoha, M. A., Ibadan, NCEMA

Park, K., Ali, M., \& Chevalier, F. (2011). Strengthening indigenous technological innovation capabilities in developing countries. Journal of US - China Public Administration, 8(3): 340 - 354.

Weingast, B. R., \& Wittman, D. A. (2008). The oxford handbook of political economy. Oxford University Press, Oxford UK. Chapter 7, 28-31. 